ISSN 2661-2666( Online) International Scientific Journal "Monte” DOI : 10.33807/monte.1.201904248 ISSN 2661-264X (Print)

\title{
TOURISM DEVELOPMENT OF KOSOVO AS A TOURIST DESTINATION
}

\author{
Dr.sc. Petrit Hasanaj \\ College "Iliria” Prishtina, petrit.hasanaj@uiliria.org \\ Dr.Sc. Artan Nimani \\ University “Ukshin Hoti” Prizren, artan.nimani@uni-prizren.com \\ Dr.Sc. Bekë Kuqi \\ University “Haxhi Zeka” Peja, beke.kuqi@unhz.eu
}

\begin{abstract}
:
Managing tourist destinations is the use of tourism potential of a country for tourism development and national economy in general, requires analytical tools and policies as part of development programs. The correct understanding of structural elements and dynamic processes is a very important factor in the development of a tourist destination.

Kosovo does not have direct access to the sea but has a mountainous hilly character, has a very favorable climate and many natural resources and a rich cultural and historical heritage that are considered as the basis for further tourism development. The purpose of this research is to study the development of tourism in Kosovo and through it is intended to make an important contribution in solving the best models of sustainable tourism development in this region. The Republic of Kosovo is in the phase of change and fundamental development where tourism is considered a very important source for the development of the country's general economy.

According to ministry data, tourism has been identified as one of the most powerful sectors for economic development and a very important market for foreign direct investment.

The Republic of Kosovo pays special attention to tourism and food, due to the climatic conditions and nature that can be used for the development and promotion of tourism as well as due to the great and unparalleled cultural and historical wealth as a very important part of the country's cumulative tourist offer.
\end{abstract}

Key words: Tourism, development, destinations, management, regions. 
ISSN 2661-2666( Online) International Scientific Journal “Monte” DOI : 10.33807/monte.1.201904248 ISSN 2661-264X (Print)

\section{Introduction}

Tourism is an economic activity oriented towards the utilization of tourist potentials. With all the difficulties and problems in different phases of Kosovo's economic development, this activity is already in harmony with Kosovo's economic development. Tourism is turning into the main sector of economic development with revenue generation and job creation. However, as one of the sectors where the country's economic growth is expected to focus on in the future, tourism is still not finding itself in sectoral development. One of the many problems facing Kosovo's tourism economy today is the identification of the tourism product development strategy, which will lead to sustainable tourism development. Culture is part of the tourist offer and has the potential to become attractive to a tourist destination and is one of the main sources of the heritage of a population. Kosovo's cultural heritage is well-known inside and outside the country and is attractive to tourists who want to see masterpieces of art and culture and learn about the evidence of prehistory, classics, Illyrian period and so on. In addition to the famous museums, there are large collections of objects in Kosovo from all aspects of life, nature, art and the like.

\section{Research Methodology}

In this research we have analyzed a number of qualitative and quantitative elements for it identify and analyze the tourism potential of Kosovo and the importance of tourism in its economic development. The realization of the goals set in the research of this topic is based on the combination of certain methods and will most often be guided by the inductive method (by exploring the general specification where the conclusions are taken according to the facts and the existing premises in order to verify the data and operationalization of concepts) and the deductive method (exploring the general to specific). The development of this topic uses primary and secondary data, ie official data presented in all types of documents, and analyzes the most relevant data and information for confirming real-life images in the stated relationship system. Based on this data, we will try to build the right conclusions.

For phenomena for which there is no data and official information, which are important for the perception of the situation and tendencies in the field of tourism, they will be processed in a qualitative way. This research tries to analyze the behavior of participants in the tourist destination and the understanding of the dynamics of the development of the tourist destination. 
ISSN 2661-2666( Online) International Scientific Journal "Monte" DOI : $\underline{\text { 10.33807/monte.1.201904248 }}$ ISSN 2661-264X (Print)

\section{A brief historical summary of the development of tourism in Kosovo}

Tourism is an economic activity oriented towards the utilization of tourist potentials. With all the difficulties and problems in the different phases of Kosovo's economic development, this activity is already in harmony with Kosovo's economic development. Although it has considerable tourist potential in Kosovo, this activity is still not considered as important in the overall economy of the country. Tourism development can contribute to the country's GDP growth and thus adapt where its country is in the country's economic development strategy. The Republic of Kosovo has recently been introduced to the tourism market as a tourist destination due to the years of isolation and problems that arose due to the lack of networks and communication links. Following the development of the Adriatic highway and the Ibris motorway in 1971, Kosovo began to affirm itself as a potential tourist market. By 1970, as far as tourism was concerned, Kosovo was a very undeveloped country. Here the first place refers to the creation of accommodation facilities for tourists who are then built only for the needs of the economy (business trips), but also for the needs of the local population, such as hotel and restaurant facilities. The first assessment is that tourism development in Kosovo remains very timely, compared to the dynamics of tourism development in the then federation. This was as a result of the concept of Kosovo's economic development only for the production of raw materials and semi-raw materials.

\section{Touristic movements up to 1990}

In this period, although it is an important part of the overall economy, tourism in Kosovo can not yet be found in a sustainable developmentKosovo is characterized by a low level of economic development due to violent economic measures and the recent war, the very slow process of privatization, small foreign investments and the like. Of course, tourism was an integral part of these negative economic and political processes. In the late 1980s and early 1990s there were major problems in the Kosovo economy (Ministry of Trade and Industry http://www.mti-ks.org/sq/ Tourism-Hospitality-and-turnover-and-historical -1989-1999).

- Administrative constraints have been established for all hotel establishments;

- The number of employees in the tourism and hospitality sector drastically decreases;

- Legal regulations on the transformation of social capital, concessions and joint investments have been approved and through fictitious transactions the enterprises with the tourist capital receive "new owners"; 
ISSN 2661-2666( Online) International Scientific Journal "Monte” DOI : 10.33807/monte.1.201904248 ISSN 2661-264X (Print)

- The start of investment in tourism and the maintenance of existing tourist facilities are interrupted;

- Interruption of investment in new lines in the field of telecommunications and related technologies..

\section{Tourism in the period $1991-2000$}

If we analyze the ten-year period from 1991 to 2000, then the following tourist turnover can be noticed:

Table no. 1. Tourism turnover for the period 1991 - 2000

\begin{tabular}{|l|l|l|l|l|l|l|l|}
\hline Year & Number & \multicolumn{2}{l}{ of } & \multicolumn{2}{l|}{ Tourists } & \multicolumn{2}{l|}{ Total } \\
\cline { 3 - 8 } & work units & internal & stranger & internal & stranger & internal & stranger \\
\hline 1991 & 54 & 130000 & 15000 & 744000 & 28000 & 145000 & 772000 \\
\hline 1992 & 46 & 103498 & 4090 & 566174 & 9099 & 107588 & 575273 \\
\hline 1993 & 46 & 103145 & 3029 & 432747 & 8857 & 106374 & 441604 \\
\hline 1994 & 50 & 90840 & 2675 & 324136 & 6882 & 93515 & 331018 \\
\hline 1995 & 50 & 88694 & 4676 & 253328 & 8690 & 93370 & 262018 \\
\hline 1996 & 50 & 107231 & 2299 & 285609 & 4986 & 109530 & 290595 \\
\hline 1997 & 50 & 76773 & 2532 & 269920 & 6934 & 80305 & 274854 \\
\hline 1998 & 50 & 72351 & 2645 & 351842 & 4981 & 74996 & 356823 \\
\hline 1999 & 50 & 38075 & 4974 & 179269 & 19005 & 43049 & 198274 \\
\hline 2000 & 23 & 32610 & 12616 & 7952 & 55720 & 45226 & 63672 \\
\hline
\end{tabular}

Source: State Statistical Office of Kosovo, 2001

From the data it can be noticed that:

- The number of tourists in 1991 was a total of 130000 tourists, and in 2000 this number has dropped to 32610 tourists (with the 9th fall);

- The number of foreign tourists in 1991 was 15,000 tourists, and in 2000 this number was 12616 tourists;;

- In 1991, 744,000 overnight stays were made by local tourists, and in 2000 this number dropped to 7,952 arrivals (10,000 reduction);

- In 1991, foreign tourists made 28,000 stays overnight, and in 2000 they made 55,720 nights (2 more for foreign soldiers).

The same is with the capacity to accommodate tourists, where there is a decrease in the number of rooms and beds. 
ISSN 2661-2666( Online) International Scientific Journal "Monte” DOI : $\underline{\text { 10.33807/monte.1.201904248 }}$ ISSN 2661-264X (Print)

Table no. 2. Number of rooms and beds in the period $1991-2000$

\begin{tabular}{|l|l|l|l|l|l|l|l|}
\hline Year & \multirow{2}{*}{$\begin{array}{l}\text { Number } \\
\text { of work }\end{array}$} & \multirow{2}{*}{$\begin{array}{l}\text { Number } \\
\text { of rooms }\end{array}$} & & \multicolumn{2}{|l|}{ Number of beds } & \multirow{2}{*}{$\begin{array}{l}\text { Number } \\
\text { of chairs }\end{array}$} & $\begin{array}{l}\text { Number of } \\
\text { employees }\end{array}$ \\
\cline { 7 - 8 } & & & & & & \\
\hline 1991 & 54 & 3515 & 7329 & 498 & 7827 & 61291 & 6077 \\
\hline 1992 & 46 & 2523 & 5277 & 492 & 5769 & 69064 & 5947 \\
\hline 1993 & 46 & 2571 & 5277 & 492 & 5769 & 68660 & 6435 \\
\hline 1995 & 50 & 2599 & 5683 & 423 & 6106 & 74352 & 6563 \\
\hline 1995 & 50 & 2599 & 5683 & 423 & 6106 & 27856 & 3662 \\
\hline 1996 & 50 & 2613 & 5739 & 407 & 6146 & 27300 & 3796 \\
\hline 1997 & 50 & 2609 & 5728 & 407 & 6135 & 27004 & 3921 \\
\hline 1998 & 50 & 2588 & 5670 & 403 & 6073 & 29938 & 3914 \\
\hline 1999 & 50 & 2614 & 5885 & 373 & 6258 & - & - \\
\hline 2000 & 23 & 938 & 1547 & 134 & 1681 & 3740 & 885 \\
\hline
\end{tabular}

Source: State Statistical Office of Kosovo, 2001

According to the data in Table no. 2 it can be noticed that the number of rooms has dropped steadily over that period, from 3515 rooms in 1991, this number dropped to 938 in 2000.

The same was the situation with the number of beds, so in 1991 there were 7827 beds (7329 permanent and 498 assistants), and in 2000 this number reached 1681 (1547 permanent beds and 134 extra beds). So, from 1991 to 2000, all the categories mentioned in the table show a drastic decline in values. There is a period when the number of rooms is unchanged, as well as the number of beds. A feature of Kosovo's tourism in the mid-1990s was the opening of a number of travel agencies, although none of them met the minimum technical requirements to do business. Most of these travel agencies deal only with the sale of airline tickets or passenger transport.

In the period 1998-1999, Kosovo's total potential destruction of tourism potentials and capacities has taken place, which are so small. In this period, the mass destruction of property that has been created over the years, with which Kosovo finds itself in a devastated economy after the end of the military conflict, occurs. Immediately after the war in Kosovo, tourism has an important place in economic activation or "restart" of the country, so tourism in the country's GDP is estimated to cover 6-7\%, and compared to that of the 1970s. the percentage was between 1.92.3\%. Increasing the share of tourism in the domestic product is a result of the drastic reduction of other private and public sector activities due to well-known reasons, and now due to the 
ISSN 2661-2666( Online) International Scientific Journal "Monte” DOI : 10.33807/monte.1.201904248 ISSN 2661-264X (Print)

changes that have occurred in the macroeconomic environment and private sector vitality in the sector hospitality and catering (The State Statistical Office of Kosovo and the Ministry of Trade and Industry Pristina 2012).

\section{Development of Kosovo's tourism in the new century}

The number of enterprises and employees in the tourism and hospitality sector in Kosovo is ranked 4th, according to local and foreign experts. Only during 2001-2002, the number of enterprises in the tourism sector increased by 862 or $55 \%$ compared to the previous years. In total employment, 237 enterprises employed 1548 workers for nine months, or $7.7 \%$ more.

The spatial distribution of tourist enterprises was almost equal for all municipalities in Kosovo, and in accordance with economic activity, so that:

- Prishtina participates with $32.1 \%$ (1373 enterprise),

- Prizreni participates with $12.4 \%$ (530 enterprise),

- Mitrovica participates with 6.7\% (288 ndërmarrje),

- Gilani participates with 5.6\% (239 enterprise),

- Gjakova participates with 4.6\% (196 enterprise),

- Peja participates with 3.8\% (165 enterprise),

- Ferizaj participates with $2.4 \%$ (102 enterprise).

According to the available data, it can be seen that in the number of employees Pristina is ranked first with 3078 employees in the tourism sector or $28.2 \%$ of the total number. After 1999 , until 2002, compared with the pre-war period, it can be noticed that major changes have been made in terms of the structure of accommodation capacities of tourists and the mode of exploitation. However, the relationship between core and complementary capacities is disadvantageous as the number of basic accommodation facilities is $48.5 \%$ compared to $51.5 \%$ of additional capacity.

In the territory of Kosovo, the hotel activity is carried out over 100 hotels and according to table data it is noticed that most hotel companies are located in the regions of Prishtina, Ferizaj and Peja.

Table no. 3. Hotel capacities in Kosovo at 2017

\begin{tabular}{|c|c|c|c|c|}
\hline ID Region & Region & Number of hotels & Number of rooms & Number of beds \\
\hline 1 & Gjakovë & 10 & 200 & 288 \\
\hline 2 & Gjilan & 9 & 172 & 221 \\
\hline
\end{tabular}


ISSN 2661-2666( Online) International Scientific Journal “Monte” DOI : 10.33807/monte.1.201904248 ISSN 2661-264X (Print)

\begin{tabular}{|c|c|c|c|c|}
\hline 3 & Mitrovicë & 6 & 119 & 128 \\
\hline 4 & Pejë & 37 & 635 & 1.265 \\
\hline 5 & Prizren & 9 & 244 & 511 \\
\hline 6 & Prishtinë & 51 & 1.588 & 2.090 \\
\hline 7 & Ferizaj & 15 & 315 & 357 \\
\hline \multicolumn{2}{|r|}{ Total } & 137 & 3,273 & 4,860 \\
\hline
\end{tabular}

Source: State Office and Statistics of Kosovo, 2017.

Of the 137 hotels operating in these regions, 103 hotels operate in the three areas mentioned above, or $75.18 \%$ of the total. In the three largest regions of these hotels there are a total of 2,538 rooms, respectively $77.54 \%$ and 3,712 beds, or $76.37 \%$ of the total number of registered beds (http://ask.rks-gov.net/).

On the other hand, the use of hotel facilities for the period 2013-2017 can be noted from the table below:

Table no. 4. Capacity utilization in Kosovo regions in percentage for the period 20132017

\begin{tabular}{|l|l|l|l|l|l|l|l|l|}
\hline $\begin{array}{l}\text { Region } \\
\text { / year }\end{array}$ & $\begin{array}{l}\text { Gjakov } \\
\text { a }\end{array}$ & Gjilani & Mitrovica & Peja & Prizreni & Pristina & Ferizaj & Total(\%) \\
\hline 2013 & 1,64 & 3,48 & 2,99 & 3,77 & 4,57 & 18,43 & 12,58 & 6,78 \\
\hline 2014 & 3,78 & 1,73 & 2,30 & 14,48 & 4,29 & 17,21 & 2,10 & 6,55 \\
\hline 2015 & 5,44 & 4,51 & 6,53 & 24,33 & 11,67 & 25,05 & 4,93 & 11,78 \\
\hline 2016 & 5,39 & 2,43 & 4,00 & 9,17 & 5,36 & 17,52 & 4,38 & 10,11 \\
\hline 2017 & 3,50 & 5,12 & 9,22 & 9,26 & 13,42 & 15,52 & 5,00 & 11,54 \\
\hline
\end{tabular}

Source: State Statistical Office in Kosovo, 2017.

According to the survey, the utilized capacity at the country level is $11.54 \%$; for more see Table, which presents the use of hotel capacities in Kosovo at country level according to region. According to the survey data, we can see that the use of state-level capacities is very low, ie in 2013 it was $6.78 \%$, in 2014 it was reduced to 6.55\%, while in 2015 there is almost twice the growth capacity of $11.78 \%$, in 2017 , is $11.54 \%$.

The region with the highest capacity utilization for the period 2013-2017 is the region of Pristina, the second is the Peja region and the third is the Prizren region.

\section{Number of tourists and stay at night}

In recent years it can be noticed that there is an increase in the number of tourists and nights spent in Kosovo and these data are presented in the table below:

Table no. 5. Number of tourists and stay within the regions for the period 2013-2017

\begin{tabular}{|l|l|l|l|l|l|}
\hline Regions & 2013 & 2014 & 2015 & 2016 & 2017 \\
\hline
\end{tabular}


ISSN 2661-2666( Online) International Scientific Journal “Monte” DOI : $\underline{10.33807 / m o n t e .1 .201904248}$ ISSN 2661-264X (Print)

\begin{tabular}{|l|l|l|l|l|l|l|l|l|l|l|}
\hline & Tourists & Nights & Tourists & Nights & Tourists & Nights & Tourists & Nights & Tourists & Nights \\
\hline Gjakova & 547 & 1.062 & 1.003 & 2.389 & 1.267 & 3.836 & 2.345 & 4.516 & 2,450 & 4.960 \\
\hline Gjilani & 737 & 1.198 & 794 & 1.222 & 712 & 1.109 & 1.109 & 1.973 & 1.239 & 2.130 \\
\hline Mitrovica & 616 & 692 & 532 & 532 & 385 & 414 & 646 & 745 & 953 & 1.089 \\
\hline Peja & 1.326 & 3.733 & 5.761 & 9.197 & 12.694 & 17.224 & 12.649 & 18.348 & 10.929 & 24.968 \\
\hline Prizreni & 3.799 & 5.521 & 3.520 & 5.694 & 9.779 & 13.947 & 9.101 & 13.044 & 8.792 & 13.942 \\
\hline Prishtina & 42.083 & 70.517 & 49.041 & 82.194 & 53.057 & 82.561 & 56.291 & 90.998 & 59.091 & 94.591 \\
\hline Ferizaji & 966 & 1.160 & 662 & 837 & 1.344 & 1.578 & 1.569 & 2.161 & 2.578 & 3.056 \\
\hline Total & 50.074 & 83.883 & 61.313 & 102.066 & 79.238 & 120.669 & 83.710 & 131.785 & 86.032 & 144.736 \\
\hline
\end{tabular}

Source: State Office and Statistics of Kosovo, 2017.

From the data it can be seen that the number of tourists in 2013 was over 50 thousand, which carried out almost 83.883 thousand nights.

This number increased in 2014 to 61,313 tourists, who stayed over 102.066 nights, while in 2017 we have a completely different situation, because in that year 86,032 tourists stayed and 144.736 nights were realized. Most of all regions is Prishtina, with almost $68 \%$ of the number of tourists in 2017 and over $66 \%$ of all attitudes in that year, and the situation is similar for the years to come. Graphically it looks like this:

Graphic appearance no. 1. Number of tourists and stay overnight for the year $2013-2017$

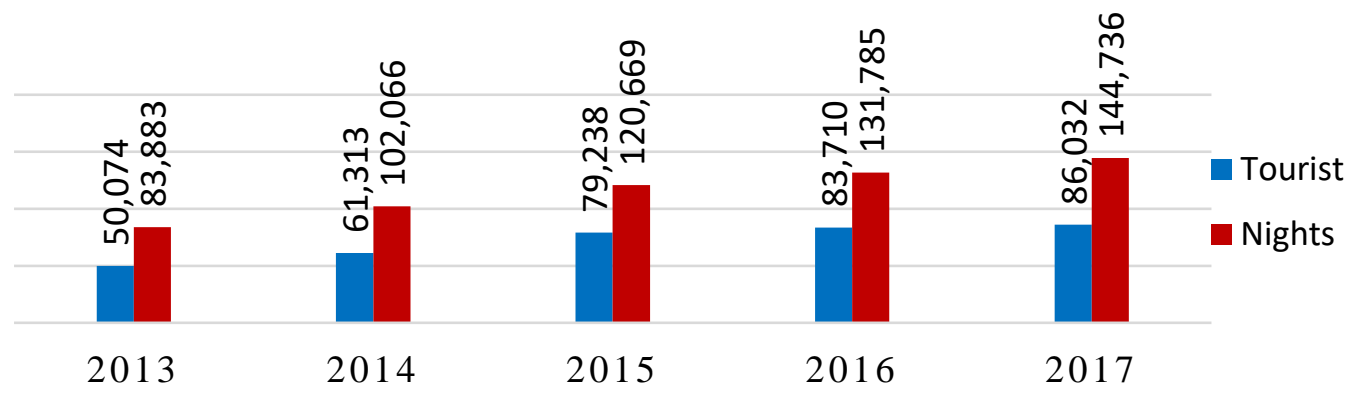

Source: State Office and Statistics of Kosovo, 2017.

As for foreign tourists for the period 2013-2015, data on their number and attitudes realized overnight can be seen from the following table:

Table no. 6. Number of foreign visitors and their nights of stay according to the region for the period Q4 of the years 2015 - 2017

\begin{tabular}{|l|l|l|l|l|l|l|}
\hline \multirow{2}{*}{ Regions } & \multicolumn{3}{|l|}{ Q4 2015} & Q4 2016 & \multicolumn{2}{l|}{ Q4 2017 } \\
\cline { 2 - 6 } & Tourists & Nights & Tourists & Nights & Tourists & Nights \\
\hline
\end{tabular}


ISSN 2661-2666( Online) International Scientific Journal “Monte” DOI : $\underline{10.33807 / m o n t e .1 .201904248}$ ISSN 2661-264X (Print)

\begin{tabular}{|l|l|l|l|l|l|l|}
\hline Gjakova & 305 & 867 & 518 & 1.137 & 356 & 522 \\
\hline Gjilani & 43 & 55 & 166 & 266 & 432 & 819 \\
\hline Mitrovica & 51 & 51 & 125 & 132 & 231 & 299 \\
\hline Peja & 1.313 & 2.062 & 1.948 & 4.435 & 1.599 & 4.291 \\
\hline Prizreni & 2.369 & 3.429 & 1.407 & 2.130 & 2.271 & 4.557 \\
\hline Pristina & 13.188 & 21.182 & 13.913 & 21.532 & 14.513 & 25.379 \\
\hline Ferizaji & 635 & 644 & 567 & 894 & 1.130 & 1.406 \\
\hline Total: & 17.904 & 28.290 & 18.644 & 30.526 & 20.532 & 37.273 \\
\hline
\end{tabular}

Source: State Statistical Office of Kosovo, 2017.

According to the data from the table, in Q4 2015, 17,904 foreign tourists stayed in Kosovo and there were 28290 night stands, in Q4 2016 there were 18,644 foreign tourists and 30,526 night stands, while in Q4 2017 there were 20,532 foreign tourists which made 37,273 night stands.

Pristina region and foreign tourists and night stands are ranked first, while the Peja region has the highest growth in the mentioned years.

\section{Foreign tourists who mainly visit Kosovo}

Table no. 7. Number of foreign guests and night stays by country of origin 2013-2017

\begin{tabular}{|l|l|l|l|l|l|l|l|l|l|l|}
\hline \multirow{2}{*}{ Country } & 2013 & 2014 & 2015 & 2016 & 2017 \\
\cline { 2 - 11 } & Tourists & Nights & Tourists & Nights & Tourists & Nights & Tourists & Nights & Tourists & Nights \\
\hline Austria & 127 & 139 & 856 & 1.435 & 451 & 680 & 500 & 1.320 & 233 & 1.107 \\
\hline Belgium & 62 & 80 & 100 & 148 & 85 & 108 & 43 & 43 & 108 & 139 \\
\hline BiH & 167 & 193 & 880 & 1.038 & 269 & 393 & 212 & 390 & 136 & 549 \\
\hline Great Britain & 1.487 & 3.919 & 2.202 & 4.204 & 1.296 & 2.571 & 1.251 & 2.539 & 289 & 4.071 \\
\hline France & 288 & 488 & 851 & 1.068 & 423 & 601 & 301 & 409 & 151 & 875 \\
\hline Germany & 734 & 4.517 & 3.598 & 7.211 & 2.941 & 8.413 & 2.750 & 8.730 & 716 & 6.279 \\
\hline Greece & 1.578 & 187 & 513 & 554 & 114 & 155 & 37 & 63 & 13 & 287 \\
\hline Netherlands & 84 & 157 & 317 & 632 & 993 & 342 & 278 & 505 & 99 & 850 \\
\hline Italy & 1.089 & 2.427 & 1.429 & 1.945 & 1.512 & 2.320 & 1.938 & 2.595 & 175 & 6.365 \\
\hline Croatia & 931 & 1.060 & 1.138 & 2.901 & 950 & 1.752 & 871 & 1.973 & 298 & 3.344 \\
\hline Montenegro & 166 & 191 & 350 & 1.434 & 270 & 2.195 & 181 & 264 & 51 & 1.099 \\
\hline Macedonia & 1.195 & 1.374 & 1.576 & 5.958 & 935 & 1.284 & 713 & 969 & 305 & 977 \\
\hline Poland & 89 & 97 & 44 & 24 & 102 & 143 & 110 & 150 & 13 & 142 \\
\hline Serbia & 250 & 233 & 578 & 446 & 558 & 705 & 515 & 708 & 195 & 1.074 \\
\hline USA & 2.450 & 5.593 & 3.279 & 5.500 & 1.867 & 4.925 & 1.628 & 3.676 & 624 & 7.670 \\
\hline Albania & 3.213 & 3.311 & 6.313 & 9.511 & 4.152 & 4.540 & 4.050 & 4.733 & 1.436 & 6.395 \\
\hline Slovenia & 1.289 & 1.823 & 1.481 & 3.145 & 1.166 & 2.017 & 1.707 & 4.120 & 461 & 7.085 \\
\hline Spain & 131 & 138 & 62 & 106 & 14 & 18 & 28 & 40 & 6 & 84 \\
\hline Turkia & 1.694 & 2.099 & 3.098 & 5.559 & 2.184 & 5.796 & 2.028 & 3.116 & 853 & 8.627 \\
\hline Switzerland & 1.452 & 2.325 & 1.245 & 1.808 & 471 & 822 & 1.061 & 1.962 & 256 & 2.157 \\
\hline Other places & 6.140 & 16.559 & 6.408 & 21.416 & 13.629 & 36.614 & 10.147 & 27.279 & 6.265 & 31.792 \\
\hline
\end{tabular}


ISSN 2661-2666( Online) International Scientific Journal “Monte” DOI : 10.33807/monte.1.201904248 ISSN 2661-264X (Print)

\begin{tabular}{|l|l|l|l|l|l|l|l|l|l|l|}
\hline Total: & 24.616 & 46.910 & 36.318 & 76.043 & 34.382 & 76.394 & 30.349 & 65.584 & 48.790 & 90.968 \\
\hline
\end{tabular}

Source: State Statistical Office in Kosovo, 2017.

In table no. 7 are represented by the number of foreign tourists and by night stay by country from which they originate, for the period 2013-2017. According to these data, the most frequent tourists visiting Kosovo come from Albania, Germany, Great Britain, Turkia and Switzerland.

According to the data, the largest number of tourists in 2017 comes from the Republic of Albania, which has also spent more nights. In 2016, tourists are also the first in Albania with 4.050 tourists, but from a standpoint in the night, tourists are from the Germany with 8.730 night stays.

In 2015, in the first place are tourists from Albania with 4.152 tourists and 4.540 night stays. The list of order includes tourists from Germany, Turkey and Switzerland.

\section{Marketing of tourist destination}

Destination marketing is now considered as a pillar for future growth and sustainability of tourism destinations in an increasingly globalized and competitive market for tourists (UNWTO. (2011). Policy and Practice for Global Tourism. Madrid: UNWTO). This argument appears today as a central element of tourism research (Fyall, A., Garrod, B., \& Wang, Y. (2012), Journal of Destination Marketing and Management), closely related to the operational activities undertaken from businesses with high competition in attracting visitors to localities. Despite the marketing efforts of destinations to market the product, sustainability is critical for all target actors due to the quality of supply throughout the tourist system (Jamrozy, U. (2007) Marketing of tourism: a paradigm shift toward sustainability, International Journal of Culture, Tourism and Hospitality Research). Destination marketing is considered as a strategic tourism management tool that should provide a balance between the stakeholders' objectives for sustainable development in the region and to guarantee the sustainability of destination resources.

\section{Conclusions}

Tourism is one of the most essential elements in the overall goals of a particular country, such as promoting the interests of its citizens, economic development and employment, regional development, managing cultural and natural heritage and strengthening the state identity of all citizens. Quality in tourism can contribute to sustainable development by improving the 
ISSN 2661-2666( Online) International Scientific Journal “Monte” DOI : 10.33807/monte.1.201904248 ISSN 2661-264X (Print)

competitiveness of the business sphere, meeting the needs of society and preserving the environment in which we live and act. Being successful at the same time in all areas listed at the level of tourist destinations needed is a global approach that will focus on meeting the needs of tourists. Improving the quality of tourist destinations is an essential necessity for tourists, which would contribute to increasing competition in the tourism industry and ensuring the development of tourism in a balanced and sustainable way.

When it comes to tourists and guests, meeting the needs arising from staying in a particular tourist destination depends not only on the experience gained through a particular tourist service but also on general factors such as hospitality, security, sewage, traffic and tourists management. Most of these factors have a direct impact on the perception of tourists for the declared tourist destination, the level of satisfaction and readiness to return or recommend it to empower tourists.

The boundaries of tourist destinations are created by combining the political and administrative capacities of the country with the help of complex networking of internal and external participants.

\section{References}

1. Ministry of Trade and Industry, Historical Reviews of Tourism and Catering for the period 1989-1999 (for more information, please contact: http://www.mti-ks.org/en/ Tourism-andHoteleria-circulation-and-historic-1989-1999.

2. Sector for Tourism of the Municipality of Pristina, 2000, p. 1

3. State Statistical Office of Kosovo and the Ministry of Trade and Industry (Enterprise Registration Department, especially those dealing with tourism), Pristina 2012

4. Ministry of Trade and Industry of the Government of the Republic of Kosovo, Ministry of Foreign Affairs of Finland and UNDP, Project entitled "Aid for Trade", Tourism Sector Profile, 2004, p. 7 - 8

5. Ministry of Trade and Industry of the Government of the Republic of Kosovo, Ministry of Foreign Affairs of Finland and UNDP, Project entitled "Aid for Trade", Tourism Sector Profile, 2004, p. 12. 
ISSN 2661-2666( Online) International Scientific Journal "Monte” DOI : 10.33807/monte.1.201904248 ISSN 2661-264X (Print)

6. Crompton, J.L. \& McKay, S.L. (1997): "Motives of visitors attending festival events". In: Annals of Tourism Research 24 (2): p425 - p439.

7. Sogojjeva, H., Mirushe Waterfalls and Their Influence on the Development of Tourism in Kosovo, Doctoral Dissertation, Faculty of Tourism and Hospitality, Ohrid, 2017, pp. 40-48.

8. Richards, G., Cultural Tourism in Europe, Atlas, 2005, стр. 25.

9. Cook J., Yale J., Marque J., Tourism: The Business of Travel, Prentice-Hall, London, 2005, p. 374.

10. Monograph on the Southern Region of Kosovo, Prizren 2012, p. 19..

11. Prizren, place of meeting of civilizations, 2012, p. 8

12. http://www.evropaelire.org/content/article/24721915.html.

13. Zagreb, 1974, Plan for development of tourism in the Kletite Mountains, and the General Urban Plan for the Mountains of the Fellows.

14. UNWTO. (2011). Policy and Practice for Global Tourism. Madrid: UNWTO.

15. Fyall, Fyall, A., Garrod, B., \& Wang, Y. (2012). Editorial. Journal of Destination Marketing and Management.

16. Jamrozy, U. (2007) Marketing of tourism: a paradigm shift toward sustainability, International Journal of Culture, Tourism and Hospitality Research. 